\title{
Inheritance of some Seed Quality and Assessment of Soluble Protein Profiles in Five Pea (Pisum sativum L.) Cultivars
}

\author{
Amein, K.A. and A.G.H. Haridy \\ ${ }^{1}$ Department of Genetics, Fac. of Agriculture, Assiut Univ., Assiut, Egypt \\ ${ }^{2}$ Department of Horticulture, Fac. of Agriculture, Assiut Univ., Assiut, Egypt \\ ${ }^{*}$ Corresponding author: Karamamein@aun.edu.eg
}

Received on: 8/4/2019

Accepted for publication on: 14/4/2019

Abstract

A half diallel set of five- parents of pea (Pisum sativum L.) was used to study the inheritance of four seed quality traits in addition to the differences in soluble protein patterns. The studied traits included 100 green seed weight, sugar percentage, starch percentage and protein content. The variances of SCA were higher in magnitude than those of GCA for total sugar and starch contents which indicated that non-additive effects were higher than the additive effects for these characters. Both additive and non-additive effects were important in controlling protein content. Meanwhile, the variance of GCA exceeded SCA by 50 folds in 100 green seed weight indicated the predominance of additive effects in the inheritance of such trait than non-additive effects. The cultivars Lincoln and Victory Freezer displayed the highest significant "gi" positive values for total sugar and 100 green seed weight. Both Master B and Dwarf Gray Sugar followed by Alaska were the best combiners for starch and protein contents. Dominance effects due to specific crosses and/or epistasis were found for all studied characters. Negative and significant correlations were observed between total sugar content and each of starch and protein contents. The electrophoretic analysis of protein profiles revealed genetic differences among the tested parents as well as among their $F_{1}$ crosses. Most of these noticeable variations were the existence of high numbers of protein bands in the hybrids as compared with their parents. The relationships among the five garden pea varieties were studied using the UPGMA cluster analysis based on data recorded from their protein profiles and the four seed traits.

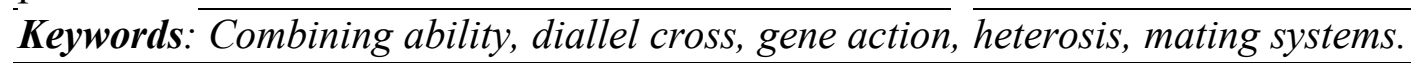

\section{Introduction}

Pea (Pisum sativum L.) is one of the important favorable vegetable crops grown in Egypt. The breeders worldwide have given a great attention to this crop. Therefore, the focus should be on selecting parents to get better recombination and superior segregations. Information on magnitude of genetic variability in the base material and the vast of variability for desired characters and There associations is needed to develop a new verity (Adams 1967, Coyne, 1968 and Zayed et al., 2005). Green peas con- tain a nutritionally favorable composition of macronutrients, protein content, low fat and high fiber (National Food Administration 1, 2002), in addition to starch with a low glycemic index (Foster-Powell et al., 1995). Among micronutrients, peas have high carotene, thiamine, ascorbic acid, riboflavin content and they are rich in iron (Nilsson, J., R., et al., 2004). Due to increased demand for protein-rich raw materials to feed animals or intermediate products for human nutrition, and high protein level (23-33\%, Cousin et al., 1985) in 
peas there is increasing interest in this crop as a source of protein (Santalla et al., 2001).

It was reported that frequent use of a few parents in breeding programs has resulted in reduced genetic diversity among pea varieties (Baranger et al. 2004). However, Nizar et al. (2011) found a significant level of variability available to breeders. They suggested that the use of varieties and genotypes of different origins are useful for genetic improvement without loss of genetic diversity in peas. The success of genetic improvement and the effectiveness of a breeding program are attributed to the nature and magnitude of genetic variability present for a specific trait. So the diverse genetic background provides a desirable allelic variation in parental lines to produce new and valuable combinations (Taran et al., 2005).

Diallel analysis (Haymen, 1954) and (Griffings, 1956) offers a potential means of obtaining information about parental combinations in terms of general and specific combining ability (GCA and SCA), direction and magnitude of dominance and overdominance and nature and extent of gene action. The estimates of GCA and SCA variances provide an appropriate diagnosis of the predominant role of additive or non-additive gene action. The GCA and SCA effects will help to locate the parents and their crosses that are responsible for bringing about particular type of gene action. (Nandarajan and Gunsekaran, 2005). GCA provides information about the importance of genes with additive effects while SCA indicates the importance of non-additive effects. Heterosis and combining ability which identify the hybrids with high performance are the most important criteria in breeding programs (Ceyhan and Avci, 2005). Cross combinations displaying hybrid vigor can be utilized for developing high yielding lines of field pea.

Heterosis or hybrid vigor in plants is the superior performance of the F1 progeny with respect to the parental lines (Shull 2007). Due to the complexity of heterosis, specific biochemical pathways have not been established to reveal a direct link to multi-genic heterosis (Rockenbach et al. 2018). However, different molecular approaches have been reported with different trends including protein accumulation, specific functions of protein, epigenetic modification, and post-transcriptional and posttranslational modifications that also regulate heterosis in different developmental stages of the plant (Chen 2013, Fu et al., 2011, Vale et al., 2016 and Xing and Sun 2016). Such, different studies have successfully been used to identify biological processes and proteins associated with heterosis in corn (Marcon et al., 2013), sunflower (Mohayeji et al., 2014), papaya [Vale et al., 2016] and popcorn (Rockenbach et al., 2018).

In view of above mentioned, the present investigation was, therefore, undertaken to study the inheritance and exploit the elite parents and their potential combinations for some important pea seed traits, in addition to the analysis of electrophoretic soluble protein profiles among five pea cultivars and their ten half-diallel crosses. 


\section{Materials and Methods}

This investigation was carried out at the Vegetable Department Experimental Farm, and the Biotechnology Laboratory, Department of Genetics, Faculty of Agriculture, Assiut University during two winter seasons, $2016 / 2017$ and 2017/2018. Seeds of five Garden pea (Pisum sativum L.) cultivars namely; Lincoln, Victory Freezer, Dwarf Gray Sugar, Alaska and Master B. were planted in preirrigated soil which had about $50 \%$ of its available moisture. In 2016, October 10 . these five cultivars were crossed to produce the 10 half-diallel crosses. In the next season, the $10 \mathrm{~F}_{1}$ crosses in addition to their 5 parents were sown in a randomized complete block design, with three replicates. The plot of each of the parental cultivars and the $F_{1}$ 's consisted of one row of 10 plants spaced $30 \mathrm{~cm}$ within 60 $\mathrm{cm}$ wide rows. The recommended cultivation practices including irrigation, fertilization and pest and weed control were applied according to Waly and Abdel-Aal (1992). The following traits were recorded: 100 green seed weight $(\mathrm{g})$, while sugar, starch and protein contents $(\mathrm{g} / 100 \mathrm{~g}$ F.W.) according to A.O.A.C. (2000) for seeds, directly after harvesting.. In addition, soluble protein profiles of the parents and their $\mathrm{F}_{1}$ hybrids were determined using SDS polyacrylamide gel electrophoresis.

\section{Statistical Analysis:}

The genetic analyses were based on the method proposed by Griffing (1956), method 2 model 1.

\section{Electrophoresis of soluble protein:}

Soluble protein was extracted in order to study the genetic differences between pea varieties and the differential expressions of proteins between pea hybrids and their parents.
Soluble proteins were extracted from pea leaves of the 5 varieties and their $10 \mathrm{~F}_{1}$ hybrids using equal volumes of the extraction buffer $(0.1 \mathrm{M}$ Tris- $\mathrm{HCl}$ $+2 \%$ glutathion $+2.0 \mathrm{mM}$ EDTA, $\mathrm{pH}$ 7.8). Protein analysis by SDS electrophoresis were carried out as described by Laemmli (1970) with $12.0 \%$ polyacrylamide and $1.0 \%$ SDS (w/v) under denaturing conditions. Protein bands were detected by staining the gel with Commassie Blue R. For good resolution of protein bands, the gel was destained by repeated immersion in the destaining mixture (1 methanol: 1 acetic acid: 8 water, by volume). The relative mobility of protein bands (Rf) were determined for each protein bands according to Philip et al. (2011). Protein bands were scored as present (1) or absent (0). Genetic similarity (Gs) and genetic distance $(\mathrm{Gd})$ were calculated according to Nei and Li (1979). The dendrogram cluster analysis based on similarity estimates was carried out by the software package MVSP (Multi-Variate Statistical Package) using the unweighted pair-group method with arithmetic average (UPGMA).

\section{Results and Discussion}

The mean performance of seed characters (total sugar, starch and protein contents) in addition to 100 green seed weight of five pea cultivars and their F1 hybrids are found in Table (1). The analyses of variance of these traits showed highly significant differences between the tested genotypes in all traits, which indicate a wide range of genetic variability for the studied traits and hence, the feasibility for genetic improvements of such genetic traits of pea seeds (Table 2). 
Table 1. Mean performance of different studied traits in five garden pea (Pisum sativum $\mathbf{L}$.) parental cultivars and their $\mathrm{F}_{1}$ half-diallel crosses.

\begin{tabular}{|l|c|c|c|c|}
\hline \multicolumn{1}{|c|}{ Genotypes } & $\begin{array}{c}\text { Total sugar } \\
\mathbf{\%}\end{array}$ & $\begin{array}{c}\text { Starch content } \\
\mathbf{\%}\end{array}$ & $\begin{array}{c}\text { Protein content } \\
\mathbf{\%}\end{array}$ & $\begin{array}{c}\mathbf{1 0 0} \text { green } \\
\text { seed weight } \\
\mathbf{( g )}\end{array}$ \\
\hline 1- Lincoln & 7.197 & 0.363 & 5.473 & 55.33 \\
\hline 2- Alaska & 6.647 & 0.917 & 5.663 & 32.33 \\
\hline 3- Victory Freezer & 6.717 & 0.183 & 5.340 & 58.33 \\
\hline 4- Master B & 6.757 & 0.520 & 5.653 & 42.00 \\
\hline 5- Dwarf Gray Sugar & 6.603 & 2.123 & 5.443 & 37.67 \\
\hline 1x2 & 6.200 & 1.357 & 5.557 & 48.33 \\
\hline $1 \times 3$ & 8.507 & 0.597 & 5.910 & 60.33 \\
\hline $1 \times 4$ & 3.370 & 2.647 & 5.173 & 50.33 \\
\hline $1 \times 5$ & 3.753 & 0.973 & 5.813 & 49.67 \\
\hline $2 \times 3$ & 4.820 & 2.763 & 6.313 & 48.33 \\
\hline $2 \times 4$ & 2.600 & 1.790 & 8.493 & 39.33 \\
\hline $2 \times 5$ & 3.310 & 1.673 & 8.493 & 36.33 \\
\hline $3 \times 4$ & 3.157 & 2.430 & 7.420 & 53.33 \\
\hline $3 \times 5$ & 3.733 & 0.543 & 8.063 & 53.00 \\
\hline $4 \times 5$ & 2.647 & 3.277 & 8.947 & 44.33 \\
\hline L.S.D 0.05 & 0.053 & 0.053 & 0.053 & 3.127 \\
\hline
\end{tabular}

Table 2. Analyses of variance for different studied traits in five garden pea cultivars and their their half diallel crosses.

\begin{tabular}{|l|c|c|c|c|c|}
\hline $\begin{array}{c}\text { Source of } \\
\text { variance }\end{array}$ & DF & $\begin{array}{c}\text { Total sugar } \\
\text { \% }\end{array}$ & $\begin{array}{c}\text { Starch content } \\
\%\end{array}$ & $\begin{array}{c}\text { Protein con- } \\
\text { tent } \%\end{array}$ & $\begin{array}{c}\text { 100 green seed } \\
\text { weight }(\mathbf{g})\end{array}$ \\
\hline reps & 2 & 0.001 & 0.001 & 0.005 & 7.400 \\
\hline genotypes & 14 & $11.40^{* *}$ & $2.953^{* *}$ & $5.498^{* *}$ & $209.9^{* *}$ \\
\hline Error & 28 & 0.001 & 0.001 & 0.001 & 3.495 \\
\hline
\end{tabular}

General (GCA) and specific (SCA) combining ability:

General and specific combining ability estimates (GCA and SCA) help in the identification of best combiner and promising parents and desirable crosses for the improvement of plant traits through selection and breeding. The variance of GCA and SCA identify the relative importance of additive and non-additive causes of variation (Peng and Virmani, 1999). In the present study, mean squares of GCA and SCA estimates were highly significant for all studied traits (Table $3)$. The variances of SCA were higher in magnitude than those of GCA for total sugar $(\mathrm{GCA} / \mathrm{SCA}=0.736)$, starch $(\mathrm{GCA} / \mathrm{SCA}=0.669)$ and protein $(\mathrm{GCA} / \mathrm{SCA}=0.933)$ contents which indicated that dominance effects were higher than the additive effects for these characters. Similarly, several studies found that the SCA variances were higher than the GCA variances for all the studied traits, thus indicating predominance of non-additive gene action for these traits (Kalia and 
Sood, 2009; Singh et al., 2010; Motamedi et al., 2014 and Singh and Lavanya, 2014).

The percentage of GCA/SCA in protein content gets relatively to the unity (0.933) indicating that both additive and non- additive effects are important in controlling this trait. Meanwhile, the variance of GCA exceeded SCA variance by 50 fold in
100 green seed weight indicated the predominance of additive effects in the inheritance of such trait than dominance effects. Similarly, Suman et al, (2017) found a predominance of additive gene effects for 100 green seed weight, therefore, it is suggested that selection in $\mathrm{F}_{1}$ generation may be either following progeny or simple recurrent selection.

Table 3. Mean squares of general (GCA) and specific (SCA) combining ability for different studied traits in five garden pea cultivars.

\begin{tabular}{|l|c|c|c|c|c|}
\hline $\begin{array}{c}\text { Source of } \\
\text { variance }\end{array}$ & DF & $\begin{array}{c}\text { Total sugar } \\
\%\end{array}$ & $\begin{array}{c}\text { Starch con- } \\
\text { tent \% }\end{array}$ & $\begin{array}{c}\text { Protein con- } \\
\text { tent \% }\end{array}$ & $\begin{array}{c}\mathbf{1 0 0} \text { green seed } \\
\text { weight }(\mathbf{g})\end{array}$ \\
\hline G.C.A. & 4 & $9.076^{* *}$ & $2.182^{* *}$ & $5.231^{* *}$ & $699.7^{* *}$ \\
\hline S.C.A. & 10 & $12.33^{* *}$ & $3.262^{* *}$ & $5.605^{* *}$ & $13.91^{* *}$ \\
\hline Error & 28 & 0.001 & 0.0005 & 0.0014 & 3.495 \\
\hline GCA/SCA & & 0.736 & 0.669 & 0.933 & 50.302 \\
\hline
\end{tabular}

The estimates of GCA effects for each parent revealed that the cultivars Lincoln and Victory Freezer displayed the highest significant "gi" positive values for total sugar and 100 green seed weight (Table 4). Both Master B and Dwarf Gray Sugar followed by Alaska were the best combiners for starch and protein contents. Meanwhile, the cultivars Alaska, Master B and Dwarf Gray Sugar displayed significant negative "gi" values indicating the existence of favorable genes for low sugar content. These results reflect the exis- tence of favorable genes for all studied traits in the tested parental genotypes, which could be utilized in the breeding programs to improve pea. This finding is coherent with that of Kalia and Sood (2009).

The significant correlations between gi estimates and the mean performance of parental genotypes in total sugar $(\mathrm{r}=0.690)$, starch content $(r=0.644)$ and 100 green seed weight $(r=0.999)$ indicated the efficiency of phenotypic value for detecting the potentiality of parents for inclusion in cross breeding programs (Table 4). 
Table 4. Estimates of general combining ability effect for different studied traits in five garden pea cultivars.

\begin{tabular}{|l|c|c|c|c|}
\hline \multicolumn{1}{|c|}{ Parents } & $\begin{array}{c}\text { Total } \\
\text { sugar \% }\end{array}$ & $\begin{array}{c}\text { Starch content } \\
\text { \% }\end{array}$ & $\begin{array}{c}\text { Protein content } \\
\text { \% }\end{array}$ & $\begin{array}{c}\text { 100 green seed } \\
\text { weight (g) }\end{array}$ \\
\hline 1- Lincoln & $0.831^{* *}$ & $-0.366^{* *}$ & $-0.815^{* *}$ & $5.105^{*}$ \\
\hline 2- Alaska & $-0.026^{* *}$ & $0.079^{* *}$ & $0.154^{* *}$ & -6.657 \\
\hline 3- Victory Freezer & $0.463^{* *}$ & $-0.309^{* *}$ & $-0.102^{* *}$ & $6.867^{* *}$ \\
\hline 4- Master B & $-0.731^{* *}$ & $0.332^{* *}$ & $0.320^{* *}$ & -1.752 \\
\hline 5- Dwarf Gray Sugar & $-0.537^{* *}$ & $0.264^{* *}$ & $0.443 * *$ & $-3.562^{* *}$ \\
\hline SE gi-gj & 0.0005 & 0.0005 & 0.0005 & 0.15 \\
\hline $\mathrm{r}_{\text {giparents }}$ & $0.690^{* *}$ & $0.644^{* *}$ & 0.311 & $0.999^{* *}$ \\
\hline
\end{tabular}

$\mathrm{r}=$ correlation between gi estimates and the mean performance of parental cultivars.

The significant amount of dominance effects (non-additive) for any trait is generally a prerequisite for exploitation of heterosis. In the present study, dominance effects due to specific crosses and/or epistasis were found for all studied characters (Table 5). Epistatic effects in the percentage of total sugar was only indicated by the highly significance of positive Sij value of the cross "1X3" followed by the cross "1X2" while; the other crosses showed significant negative $\mathrm{Sij}$ values. Three crosses (1X4, 2X3 and 4X5) revealed highly significant positive epistasis ( $\mathrm{sij}$ values) in percent of starch content while; the other crosses showed significant negative Sij values. The six crosses (1X3), (2X4), (2X5), (3X4), $(3 \times 5)$ and (4X5) displayed significant Sij positive values for percent of protein content while; the other four crosses showed significant negative Sij values. In 100 seed weight, three crosses [(1X2), (3X5) and (4X5)] showed highly significant positive sij values while; (1X3) and (3X4) showed significant positive sij values.

Table 5. Estimates of specific combining ability for different studied traits in the $\mathbf{F}_{\mathbf{1}}$ half diallel crosses of five garden pea culticars.

\begin{tabular}{|l|c|c|c|c|}
\hline Crosses & $\begin{array}{c}\text { Total sugar } \\
\mathbf{\%}\end{array}$ & $\begin{array}{c}\text { Starch content } \\
\mathbf{\%}\end{array}$ & $\begin{array}{c}\text { Protein content } \\
\mathbf{\%}\end{array}$ & $\begin{array}{c}\mathbf{1 0 0} \text { green seed weight } \\
\mathbf{( g )}\end{array}$ \\
\hline $1 \times 2$ & $0.327^{* *}$ & $0.167^{* *}$ & $-0.300^{* *}$ & $2.619^{* *}$ \\
\hline $1 \times 3$ & $2.145^{* *}$ & $-0.205^{* *}$ & $0.310^{* *}$ & $1.095^{*}$ \\
\hline $1 \times 4$ & $-1.797^{* *}$ & $1.204^{* *}$ & $-0.849^{* *}$ & -0.286 \\
\hline $1 \times 5$ & $-1.609^{* *}$ & $-0.402^{* *}$ & $-0.332^{* *}$ & 0.857 \\
\hline $2 \times 3$ & $-0.685^{* *}$ & $1.516^{* *}$ & $-0.256^{* *}$ & 0.857 \\
\hline $2 \times 4$ & $-1.710^{* *}$ & $-0.098^{* *}$ & $1.502^{* *}$ & 0.476 \\
\hline $2 \times 5$ & $-1.95^{* *}$ & $-0.147^{* *}$ & $1.379^{* *}$ & -0.714 \\
\hline $3 \times 4$ & $-1.643^{* *}$ & $0.930^{* *}$ & $0.686^{* *}$ & $0.952^{*}$ \\
\hline $3 \times 5$ & $-1.261^{* *}$ & $-0.889^{* *}$ & $1.206^{* *}$ & $2.429^{* *}$ \\
\hline $4 \times 5$ & $-1.153^{* *}$ & $1.204^{* *}$ & $1.667^{* *}$ & $2.381^{* *}$ \\
\hline SE sij-sik & 0.0002 & 0.0001 & 0.0004 & 0.893 \\
\hline
\end{tabular}




\section{Phenotypic correlation between the studied traits:}

Phenotypic correlation coefficients for all comparisons among the studied seed traits are presented in Table (6). Negative and significant correlations were observed between total sugar content and each of starch and protein contents. These findings indicate that selection for low sugar content would be accompanied by high starch content and improved protein content in pea seeds.

Table 6. Phenotypic correlation coefficients among studied traits of garden pea cultivars.

\begin{tabular}{|l|c|c|c|c|}
\hline \multicolumn{1}{|c|}{ Characters } & $\begin{array}{c}\text { Total } \\
\text { sugar \% }\end{array}$ & $\begin{array}{c}\text { Starch con- } \\
\text { tent \% }\end{array}$ & $\begin{array}{c}\text { Protein con- } \\
\text { tent \% }\end{array}$ & $\begin{array}{c}\text { 100 green seed } \\
\text { weight }(\mathbf{g})\end{array}$ \\
\hline Total sugar \% & -- & $-0.623^{* *}$ & $-0.719^{* *}$ & 0.229 \\
\hline Starch content \% & & -- & 0.386 & -0.288 \\
\hline Protein content \% & & & -- & -0.245 \\
\hline 100 green seed weight $(\mathrm{g})$ & & & & -- \\
\hline
\end{tabular}

${ }^{*}$ Correlation is significant at the 0.05 level (2-tailed). ${ }^{* *}$. Correlation is significant at the 0.01 level (2-tailed).

\section{Protein analysis:}

Electrophoretic analysis of protein patterns in the 5 parents of pea plants and their $F_{1}$ 's are found in Figure (1) and summarized in Table (7). In addition to variations in band intensity, the results showed clear variations in the number of polypeptide bands among the tested parents. The cultivars Victory Freezer and Master B showed the highest number of protein bands (13 bands, each) while the lowest (10 bands) obtained by Alaska and Dwarf Gray Sugar. Lincoln displayed 12 protein bands. These differences reflect the genetic variability between the tested parents at molecular level which was substantiated before at phenotypic level of the five studied traits (Table 2).

On the other hand, the $F_{1}$ crosses revealed quantitative and qualitative differences in their protein profiles (Fig.1 and Table 7). Most of these noticeable variations are the existence of high numbers of protein bands in the hybrids as compared with their parents. In this instance, the number of protein bands ranged from 10 to 13 in the 5 parents and from 13 (Lincoln X Dwarf Gray Sugar) to 20 (Lincoln $\mathrm{X}$ Alaska) in their $F_{1}$ hybrids. Since the $F_{1}$ crosses showed significant heterosis in one or more traits as mentioned above, these high numbers of protein bands may be due to heterosis or hybrid vigor in plants of pea crosses. In addition, this increase in gene expression as revealed by protein patterns also play an important role in hybrids during early stages of plant development for fast growing and better hybrid performance (Marcon et al., 2010 and 2013). To date, protein analysis has been successfully used to analyze heterotic patterns in wheat, corn, sunflower, papaya and popcorn (Marcon et al., 2013, Mohayeji et al., 2014, Vale et al. 2016 and Rockenbach et al., 2018). They reported that differential expressions of proteins between plant hybrids and their parents are involved in signal transduction, metabolic reaction, cell division and disease defense. 
Table 7. Survey of the soluble protein bands in in five garden pea parents and their $F_{1}$ crosses.

\begin{tabular}{|c|c|c|c|c|c|c|c|c|c|c|c|c|c|c|c|c|}
\hline \multirow{2}{*}{ No. } & \multirow{2}{*}{ RF } & \multicolumn{1}{|c|}{ Parents } & \multicolumn{10}{|c|}{ crosses } \\
\hline & & 1 & 2 & 3 & 4 & 5 & $1 \times 2$ & $1 \times 3$ & $1 \times 4$ & $1 \times 5$ & $2 \times 3$ & $2 \times 4$ & $2 \times 5$ & $3 \times 4$ & $3 \times 5$ & $4 \times 5$ \\
\hline 1 & 0.131 & 0 & 0 & 0 & 0 & 0 & 0 & 0 & 0 & 1 & 0 & 0 & 0 & 0 & 0 & \\
\hline 2 & 0.151 & 0 & 0 & 0 & 0 & 0 & 0 & 0 & 0 & 0 & 0 & 0 & 0 & 0 & 0 & 1 \\
\hline 3 & 0.165 & 0 & 1 & 1 & 1 & 0 & 1 & 1 & 0 & 0 & 1 & 1 & 1 & 0 & 1 & 1 \\
\hline 4 & 0.172 & 1 & 0 & 1 & 0 & 0 & 0 & 0 & 0 & 0 & 0 & 0 & 0 & 0 & 0 & 0 \\
\hline 5 & 0.179 & 1 & 0 & 1 & 0 & 1 & 1 & 1 & 0 & 0 & 0 & 0 & 0 & 0 & 0 & 0 \\
\hline 6 & 0.193 & 0 & 0 & 0 & 0 & 0 & 0 & 0 & 0 & 0 & 0 & 0 & 0 & 1 & 1 & 1 \\
\hline 7 & 0.207 & 0 & 0 & 0 & 0 & 0 & 1 & 1 & 1 & 1 & 0 & 1 & 0 & 0 & 1 & 1 \\
\hline 8 & 0.234 & 0 & 0 & 0 & 0 & 0 & 1 & 1 & 0 & 0 & 0 & 0 & 0 & 0 & 0 & 0 \\
\hline 9 & 0.276 & 0 & 0 & 0 & 0 & 0 & 1 & 0 & 0 & 0 & 0 & 0 & 0 & 0 & 0 & 0 \\
\hline 10 & 0.310 & 0 & 0 & 0 & 1 & 0 & 1 & 1 & 1 & 1 & 1 & 1 & 1 & 1 & 1 & 1 \\
\hline 11 & 0.324 & 0 & 0 & 0 & 0 & 0 & 1 & 1 & 1 & 0 & 0 & 1 & 1 & 0 & 1 & 1 \\
\hline 12 & 0.344 & 0 & 0 & 0 & 0 & 0 & 0 & 0 & 0 & 0 & 0 & 1 & 1 & 1 & 0 & 0 \\
\hline 13 & 0.379 & 0 & 0 & 0 & 0 & 0 & 0 & 1 & 1 & 1 & 1 & 0 & 0 & 0 & 1 & 1 \\
\hline 14 & 0.407 & 0 & 0 & 0 & 0 & 0 & 1 & 1 & 1 & 1 & 1 & 0 & 0 & 0 & 0 & 0 \\
\hline 15 & 0.469 & 1 & 1 & 0 & 1 & 1 & 1 & 1 & 1 & 1 & 1 & 1 & 1 & 1 & 0 & 1 \\
\hline 16 & 0.483 & 1 & 1 & 1 & 1 & 1 & 1 & 1 & 1 & 1 & 1 & 1 & 1 & 1 & 1 & 1 \\
\hline 17 & 0.503 & 0 & 0 & 0 & 0 & 0 & 0 & 0 & 0 & 0 & 0 & 0 & 0 & 1 & 0 & 0 \\
\hline 18 & 0.600 & 1 & 0 & 1 & 1 & 0 & 1 & 1 & 1 & 1 & 1 & 1 & 1 & 1 & 0 & 0 \\
\hline 19 & 0.621 & 1 & 1 & 1 & 1 & 1 & 1 & 1 & 1 & 1 & 1 & 1 & 1 & 1 & 1 & 1 \\
\hline 20 & 0.634 & 0 & 0 & 0 & 0 & 0 & 1 & 1 & 0 & 1 & 1 & 0 & 0 & 0 & 1 & 1 \\
\hline 21 & 0.655 & 1 & 1 & 1 & 0 & 0 & 0 & 0 & 0 & 0 & 0 & 1 & 1 & 1 & 0 & 0 \\
\hline 22 & 0.669 & 0 & 0 & 1 & 1 & 1 & 1 & 1 & 1 & 0 & 0 & 0 & 0 & 0 & 0 & 0 \\
\hline 23 & 0.703 & 1 & 1 & 1 & 1 & 1 & 1 & 1 & 1 & 1 & 1 & 1 & 1 & 1 & 1 & 1 \\
\hline 24 & 0.724 & 1 & 1 & 1 & 1 & 0 & 1 & 1 & 1 & 0 & 1 & 0 & 1 & 1 & 1 & 1 \\
\hline 25 & 0.758 & 1 & 1 & 1 & 1 & 1 & 1 & 1 & 1 & 1 & 0 & 0 & 0 & 0 & 1 & 0 \\
\hline 26 & 0.771 & 0 & 0 & 0 & 0 & 0 & 0 & 0 & 0 & 0 & 1 & 1 & 1 & 1 & 1 & 1 \\
\hline 27 & 0.827 & 1 & 1 & 1 & 1 & 1 & 1 & 1 & 1 & 1 & 1 & 1 & 1 & 1 & 1 & 1 \\
\hline 28 & 0.896 & 1 & 1 & 1 & 1 & 1 & 1 & 1 & 1 & 1 & 1 & 1 & 1 & 1 & 1 & 1 \\
\hline 29 & 0.924 & 0 & 0 & 0 & 1 & 1 & 1 & 0 & 1 & 0 & 1 & 1 & 1 & 0 & 0 & 0 \\
\hline Band & Number & 12 & 10 & 13 & 13 & 10 & 20 & 19 & 16 & 13 & 15 & 15 & 15 & 14 & 15 & 16 \\
\hline
\end{tabular}




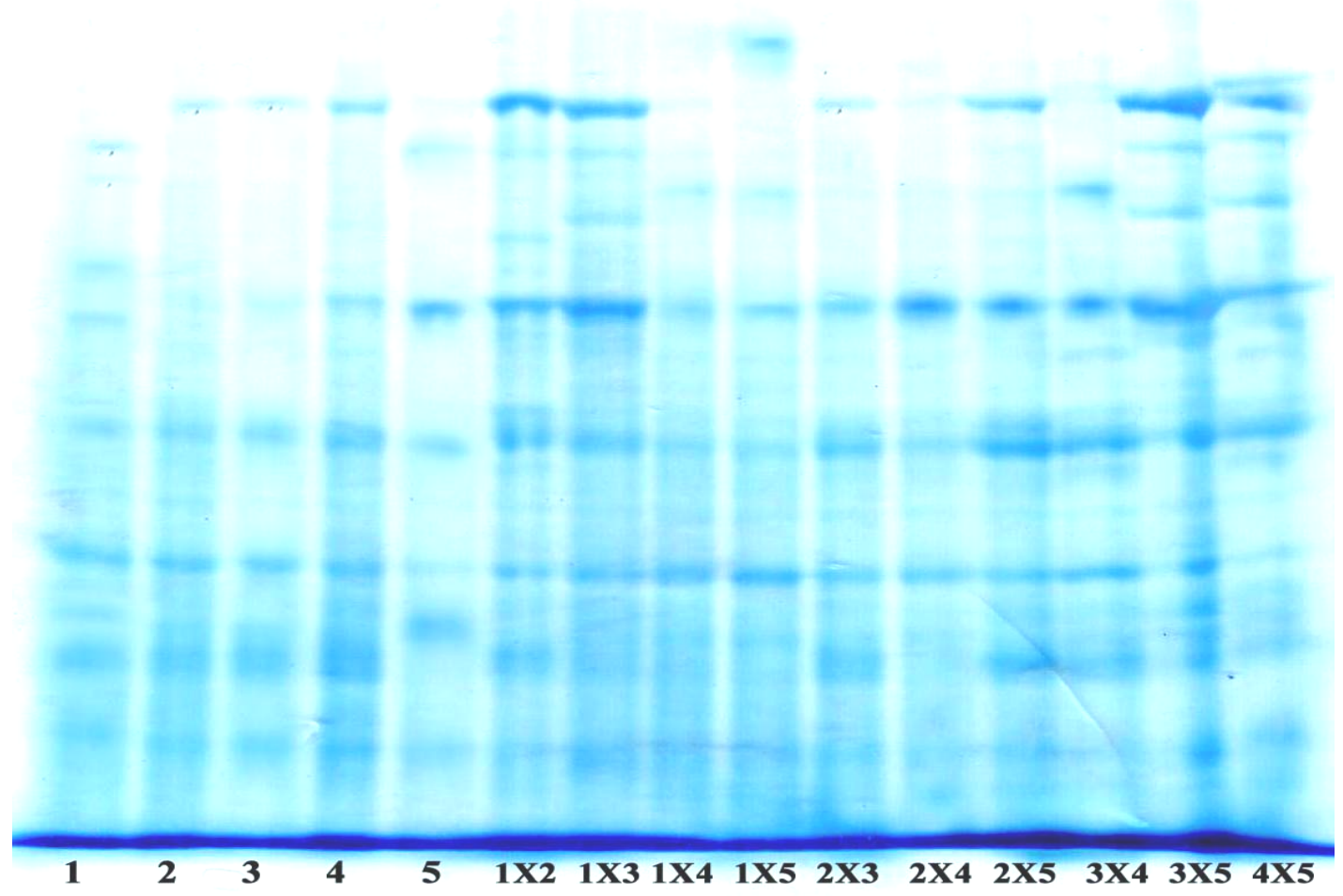

Fig. (1): Electrophoretic patterns of Protein profile detected in five garden pea parents and their $\mathrm{F}_{1}$ crosses.

Genetic relationship between the parents

Highly genetic similarity $(\mathrm{Si}=$ 78.6) and shortest genetic distance (0.241) was found between Lincoln and Victory Freezer (Table 8). While, Victory Freezer and Dwarf Gray Sugar displayed the longest genetic distance (0.629) and lowest similarity $(\mathrm{Si}=53.3)$.

These genetic distances were illustrated in the UPGMA cluster analysis (Fig. 2). The dendrogram revealed that the five parents were distributed in two main clusters within overall 57.9 genetic similarity (GS). In the $1^{\text {st }}$ cluster, Lincoln and Victory Freezer were clustered together firstly at $78.6 \mathrm{GS}$, and then clustered with Alaska within branched-off 66.8 GS. Master B and Dwarf Gray Sugar were grouped together in the $2^{\text {nd }}$ cluster at 64.3 GS.

Based on the 5 tested traits of pea seeds, the UPGMA cluster analysis of the five parents was constructed and illustrated in Fig. 3. Similar trend in the distribution of parents was observed in both protein based dendrogram and seed-traits dendrogram. In the dendrogram based on seed-traits, Lincoln and Victory Freezer were grouped together firstly in the $1^{\text {st }}$ cluster while Master B and Dwarf Gray Sugar found in the $2^{\text {nd }}$ cluster and then with Alaska. These results 
reflect the close correlation between the studied traits of pea seeds and gene expression as revealed by protein patterns in the five pea varieties.

Table 8. Genetic similarity (lower left diagonal) and distance (higher right diagonal) values between the five garden pea cultivars calculated using their soluble protein profiles.

\begin{tabular}{|l|c|c|c|c|c|}
\hline \multicolumn{1}{|c|}{ pea varieties } & $\mathbf{1}$ & $\mathbf{2}$ & $\mathbf{3}$ & $\mathbf{4}$ & $\mathbf{5}$ \\
\hline 1- Lincoln & -- & 0.368 & 0.241 & 0.574 & 0.562 \\
\hline 2- Alaska & 69.2 & -- & 0.441 & 0.441 & 0.619 \\
\hline 3- Victory Freezer & 78.6 & 64.3 & -- & 0.470 & 0.629 \\
\hline 4- Master B & 56.3 & 64.3 & 62.5 & -- & 0.441 \\
\hline 5- Dwarf Gray Sugar & 57.0 & 53.8 & 53.3 & 64.3 & -- \\
\hline
\end{tabular}

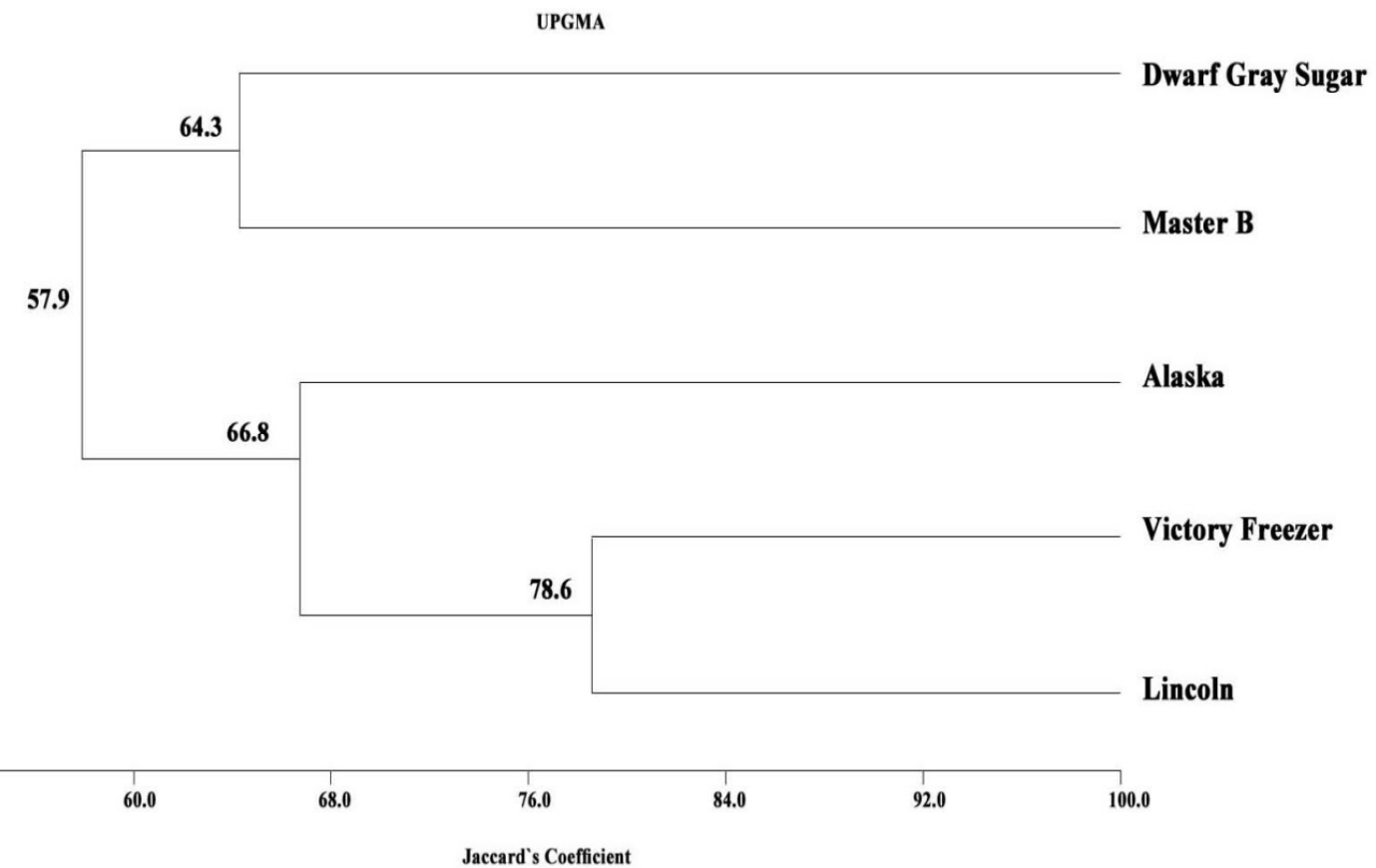

Fig. (2): Dendrogram demonstrating the relationships among five garden pea cultivars based on data recorded from their soluble protein profiles. 


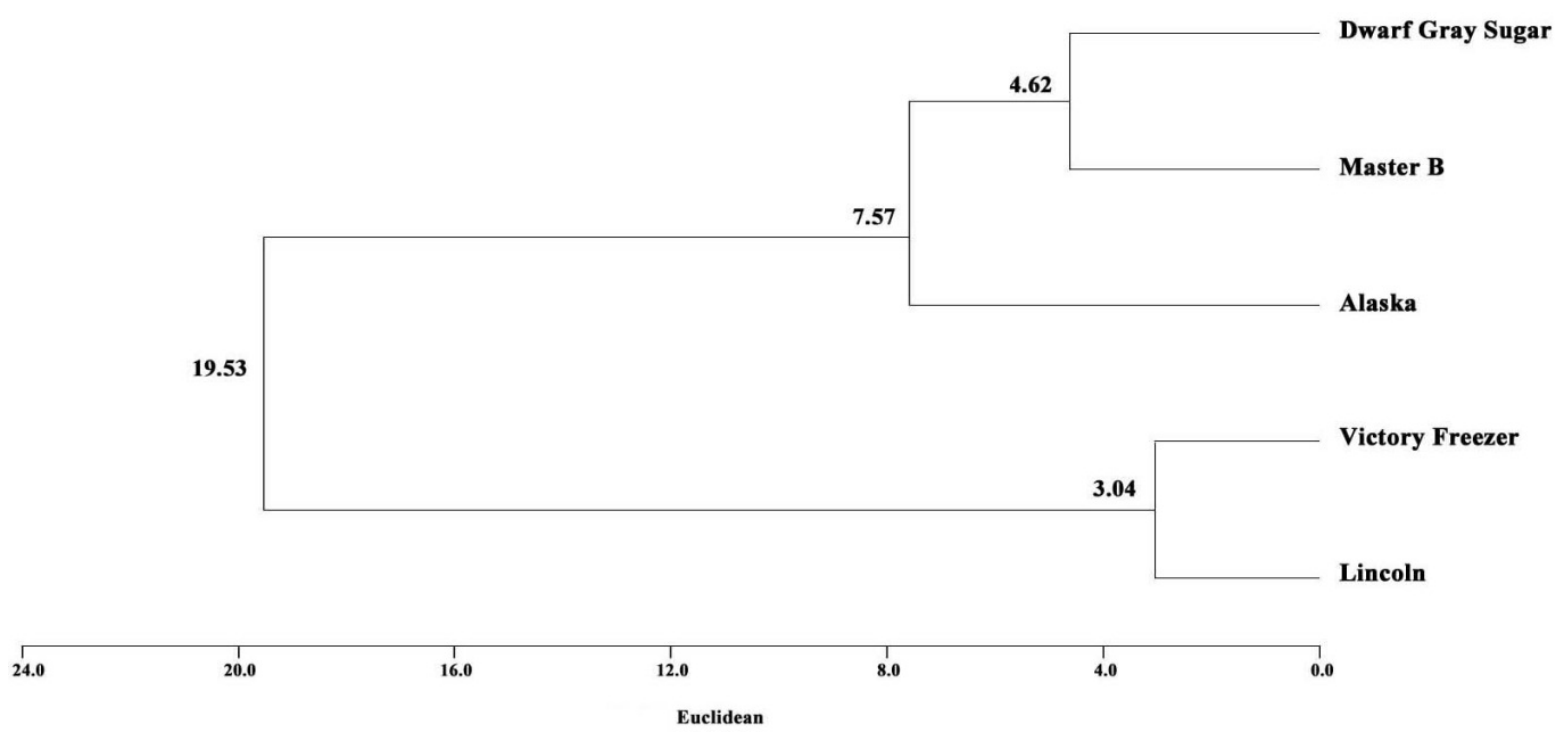

Fig. (3): Dendrogram demonstrating the relationships among five garden pea cultivars based on data recorded from the four seed traits.

\section{References}

Adams, M.W. 1967. Basis of yield component compensation in crops with special reference of field bean, Phaseolus vulgaris L. Crop Sci., 7: 637-640.

A.O.A.C., 2000. Association of Official Analytical Chemists. Official Methods 965.33. Official Methods of Analysis, 17" Ed., Gaithersburg, MD.

Baranger, A., Aubert, G., Arnau, G., Laine, A.L. 2004. Genetic diversity within Pisum sativum using protein- and PCR-based markers. Theor. Appl. Genet. 108: 13091321.

Ceyhan, E. and Avci M. A. 2005. Combining ability and heterosis for grain yield and some yield component in pea (Pisum sativum L.). Pak. J. Biol. Sci, 8 (10): 14471452.

Chen, ZJ. 2013. Genomic and epigenetic insights into the molecula rbases of heterosis. Nature reviews Genetics. $14: 471$. https://doi.org/10.1038/nrg3503 PMID:2375279411.
Cousin, R., Messager A and Vingere A 1985. Breeding for Yield in Combining Peas. In: The Pea Crop. A Basis for Improvement (Hebblethwaite PD, Heath $\mathrm{MC}$ and Dawkins TCK, eds.). Butherworkths, London, 115-129.

Coyne, D.P. 1968. Correlation, heritability and selection of yield components in field beans, Phaseolus vulgaris L. Proc. Am. Soc. Hort. Sci. 93: 338-390.

Foster-Powell, K. and J.B. Miller 1995. International tables of glycemic index, American Journal of Clinical Nutrition 62 () 871S-893S.

Fu Z, Jin X, Ding D, Li Y, Fu Z, Tang J. 2011. Proteomic analysis of heterosis during maize seed germination. Proteomics. https://doi.org/10.1002/pmic.2010 00481 PMID: 2136575312. 11: 1462-1472.

Griffings, B. 1956. Concept of general and specific combining ability in relation to diallel crossing system. Anst. J. Biol. Sci. 9 : 463-93.

Hyman, B.I. (1954). The analysis of variance of diallel tables. Biometrics, 10: 235-244. 
Kalia, P. and M. Sood. 2009. Combining ability in the F1 and F2 generations of a diallel cross for horticultural traits and protein content in garden pea (Pisum sativum L.). Sabrao J. Breeding \& Gnetics 41(1): 53-68.

Laemmli, U.K. 1970. Cleavage of structural proteins during the assembly of the head of bacteriophage T4. Nature 227: 680-685.

Marcon, C, SchuĖtzenmeister A, SchuÈ tz W, Madlung J, Piepho H-P, Hochholdinger F. 2010. Nonadditive protein accumulation patterns in maize (Zea mays L.) hybrids during embryo development. Journal of Proteome Research.; 9: 6511-

6522. https://doi.org/10.1021/pr100718d PMID: 20973536.

Marcon, C, Lamkemeyer T, Malik WA, Ungrue D, Piepho H-P, Hochholdinger F. 2013. Heterosis-associated proteome analyses of maize (Zea mays L.) seminal roots by quantitative label-free $\mathrm{LC} \pm \mathrm{MS}$. Journal of Proteomics. 93: 295-302. https://doi.org/10.1016/j.jprot.2013 .04.015 PMID: 23607940.

Mohayeji, M, Capriotti AL, Cavaliere C, Piovesana S, Samperi R, Stampachiacchiere S, et al. 2014. Heterosis profile of sunflower leaves: a label free proteomics approach. Journal of Proteomics. 99: 101110.

https://doi.org/10.1016/j.jprot.01.0 28 PMID: 24508334.

Motamedi, M.; Rajab choukan, Eslam majidi hervan, Mohammad Reza Bihamta and Farokh Darvish Kajouri 2014. Combining ability and Heterosis analysis for grain yield and yield associated traits in Pea (Pisum sativum L.) Int. J. Biosci. 5. (12): 123-129.

Nandarajan, N. and Gunasekaran, M. 2005. Quantitative genetics and biometrical techniques in plant breeding. Kalyani Publishers, New Delhi, pp109-110.

National Food Administration, Food composition database 2002. Ver. 02.2, code 1155, Uppsala, Sweden.

Nei, M. and W. H. Li 1979. Mathematical model for studying genetic variation in terms of restriction endonucleases. Proc. Natl. Acad. Sci. USA., 76: 5269-5273.

Nilsson, J., R. Stegmark and B. Akesson 2004. Total antioxidant capacity in different pea (Pisum sativum) varieties after blanching and freezing, Food Chemistry 86 (), 501507.

Nisar, M., Ghafoor, A. and Khan, M.R. 2011. Phenotypic variation in the agronomic and morphological traits of Pisum sativum L. germplasm obtained from different parts of the world. Genetika, 47: 25-31.

Peng, J.Y. and S.S. Virmani, 1999. Combining ability for yield and four related traits in relation to breeding in rice. Oryza, 37: 1-10.

Philip, L. R., Bonner, Alan J. Hargreaves 2011. Basic Bioscience Laboratory Techniques: Apocket Guide. John Wiely \& Sons. PP. 140.

Rockenbach, M.F., Corrêa C.C.G., Heringer A.S., Freitas I.L.J., SantaCatarina C., do Amaral-JuÂnior A.T. 2018. Differentially abundant proteins associated with heterosis in the primary roots of popcorn. PLoS ONE 13(5): https://doi.org/10.1371/journal.pon e.0197114.

Santalla, M, Amurrio, J. M. and De Ron, A.M. 2001. Food and feed potential breeding of green, dry and vegetable pea germplasm. Can. J. Plant Sci. 81: 601-610.

Shull, GH. 2007. What is "heterosis"? Genetics. 1948; 33: 439. PMID: 17247290 
Singh, K.P., H.C. Singh and M.C. Verma, 2010. Genetic analysis for yield and yield traits in pea Journal of Food Legumes., 23(2): 113-116.

Singh, A. and Lavanya, G.R. 2014. Character association studies in field pea (Pisum sativum L.) Trends Biosci., 7 (1): 51-53.

Suman, H.; B. Kumar, Nageshwar, M. Rathi and D. Tamatam. 2017. Heterosis and Combining Ability for Grain Yield and Yield Associated Traits in $10 \mathrm{X} 10$ Diallel Analysis in Pea (Pisum sativum L.). Int. J. Curr. Microbiol. App. Sci., 6 (12): 1574-1585.

https://doi.org/10.20546/ijcmas.20 17.612.177.

Taran, B. Zhang, C. Warkentin, T. Tullu, A. 2005. Genetic diversity among varieties and wild species accessions of pea (Pisum sativum L.) based on molecular markers, and morphological and physiological characters. Genome, 48: 257-272.
Vale, EM, Reis RS, Santa-Catarina R, Pereira MG, Santa-Catarina C, Silveira V. 2016. Comparative proteomic analysis of the heterosis phenomenon in papaya roots. Scientia Horticulturae. 209:178-186. 13.

Waly, E.A. and S.A. Abdel-Aal, 1992. Technical and extension of new faba bean. Dept. of Horticulture,Faculty of Agriculture, Assiut Univ., pp: 16.

Xing, J, Sun Q, Ni Z. 2016. Proteomic patterns associated with heterosis. Biochimica et Biophysica Acta (BBA) - Proteins and Proteomics. 1864: 908-915.

Zayed, G.A., Fawzia A. Helal and S.T. Farag 2005. The performance of some continuously variable characteristics of pea under different locations. Annals Agric. Sci., Moshtohor, 43: 337-346. 


\section{توارث بعض صفات جودة البذور وطرز البروتين القابل للأوبان فى خمسة أصناف من البسلة}

$$
\begin{aligned}
& \text { كرم عبدالنعيم امين وأشرف جلال هريدي } \\
& \text { 'قسم الور اثة - كلية الزر اعة - جامعة أسيوط } \\
& \text { "َقسم الخضر - كلية الزر اعة - جامعة أسيوط }
\end{aligned}
$$

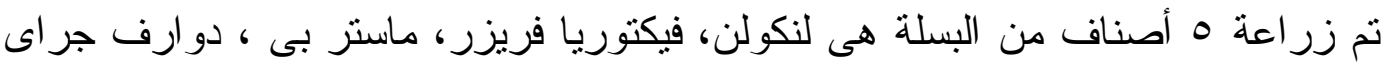

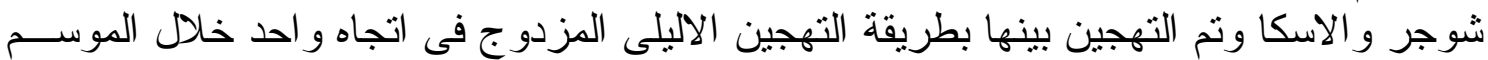

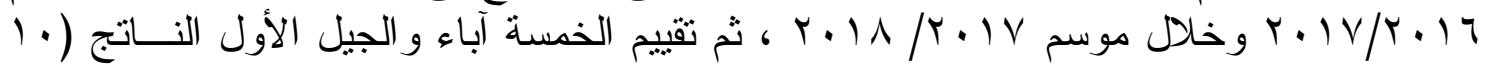

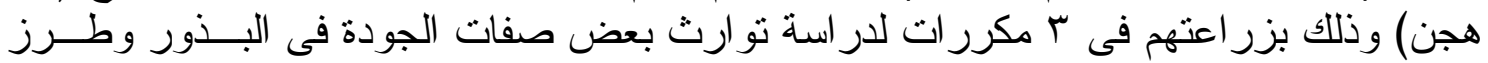

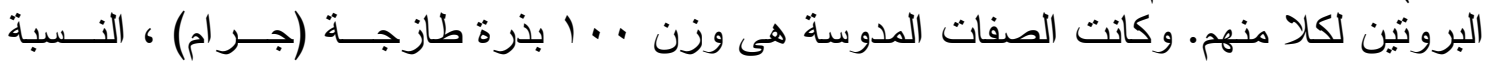

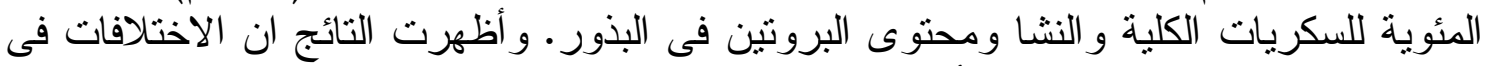

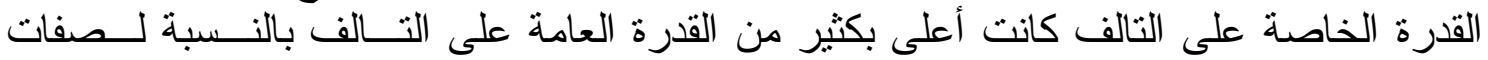

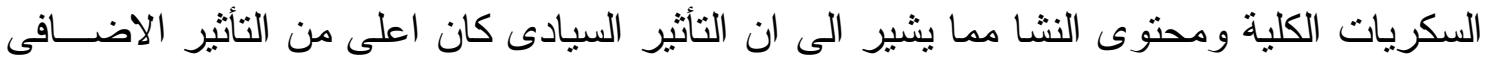

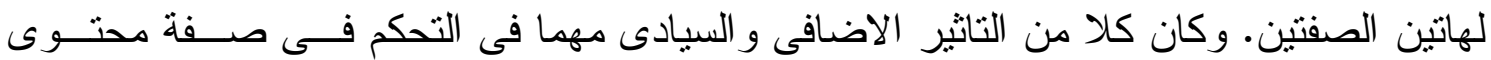

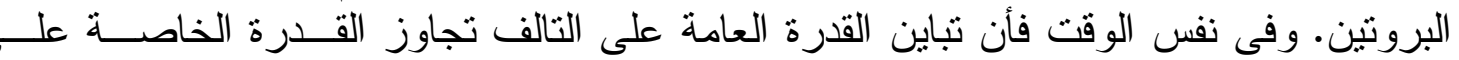

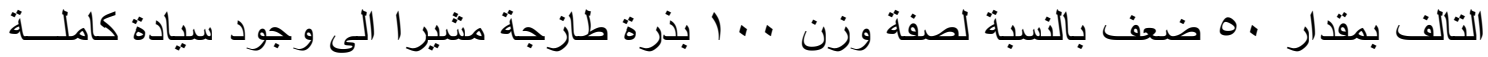

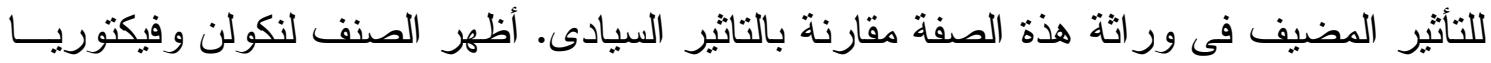

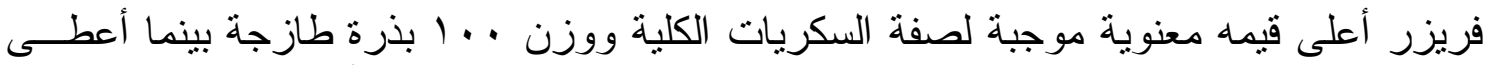

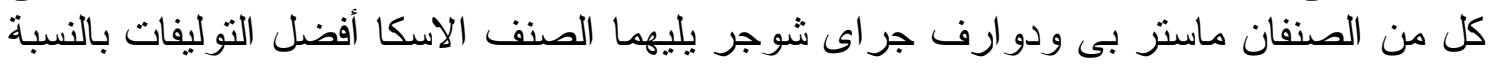

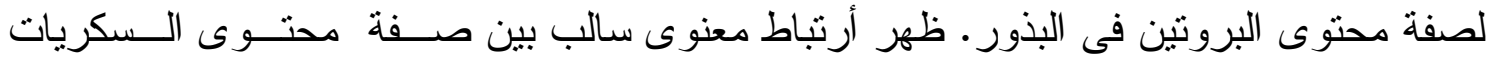

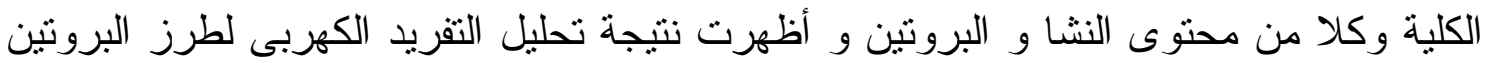

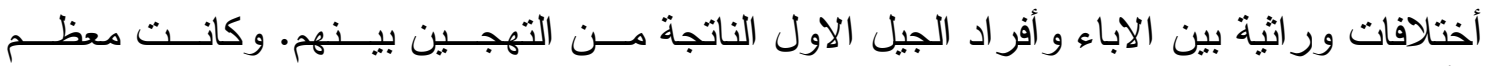

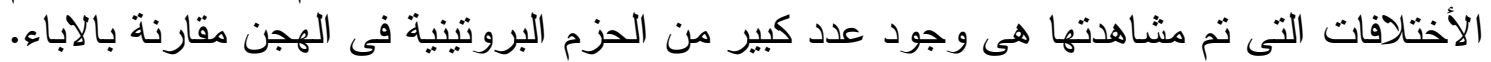

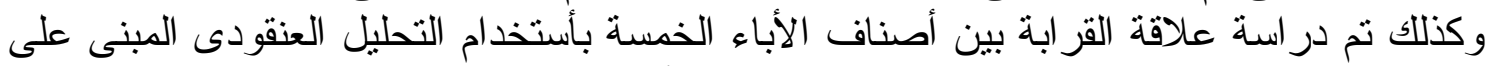

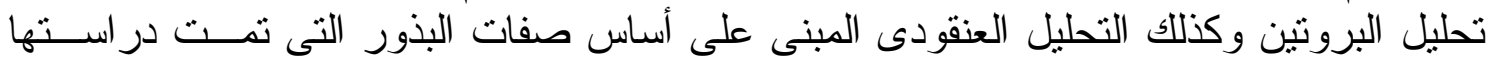
ووجد ان هناك تطابق بين نتائج كلا التحليلين. 